\title{
Determination of Hydrodynamics in Municipal Waste Water by a Lagoon System with Screens
}

\author{
M. García-Martínez¹, L. J. Osornio-Berthet', H. E. Solís-Correa1, U. J. López-Chuken², \\ J. C. Beltrán-Rocha², I. D. Barceló-Quintal ${ }^{*}$ \\ ${ }^{1}$ Basic and Engineering Division, Chemistry and Physical Chemistry of Environmental Area, University Autonomous \\ Metropolitan-Azcapotzalco, Azcapotzalco, Mexico \\ ${ }^{2}$ Laboratory of Biotechnology and Laboratory of Photocatalysis and Electrochemistry, Faculty of Chemical Sciences, UANL, \\ Mexico \\ Email: ^ibarceloq@gmail.com
}

How to cite this paper: García-Martínez, M., Osornio-Berthet, L.J., Solís-Correa, H.E., López-Chuken, U.J., Beltrán-Rocha, J.C. and Barceló-Quintal, I.D. (2017) Determination of Hydrodynamics in Municipal Waste Water by a Lagoon System with Screens. Journal of Environmental Protection, 8, 330-343.

https://doi.org/10.4236/jep.2017.83025

Received: February 12, 2017

Accepted: March 28, 2017

Published: March 31, 2017

Copyright (c) 2017 by authors and Scientific Research Publishing Inc. This work is licensed under the Creative Commons Attribution International License (CC BY 4.0).

http://creativecommons.org/licenses/by/4.0/

\begin{abstract}
Stabilization lagoons are economic systems that are built for treatment of municipal, industrial and agricultural wastewater; these systems are used in rural communities. Objective of this article is to present the hydrodynamics flow in lagoon system considering 6 screens with 7 channels containing curved forms with slopes suitable to stabilize the flow along each channel, and approach a piston flow. Hydrodynamics of this system with IBER software was analyzed, where was considered the velocity and hydraulic gradient, using Froude number. Also transport of total suspended solids was modelled. Efficiency in the treatment with this design was evaluated, using parameters such as, $\mathrm{pH}$, conductivity, alkalinity, hardness, total solids, dissolved oxygen, redox potential and Chemical Oxygen Demand (COD). Through the results, a homogeneous transport was observed, mainly dissolved oxygen which was concordant with redox potential and COD, also through the curves, short circuits were minimized, avoiding dead zones and making treatment more efficient, finally were possible to comply with regulations of Mexico NOM-001-SEMARNAT-1996 of discharges and the NOM-003-SEMARNAT-1997 for water of agricultural use.
\end{abstract}

\section{Keywords}

Stabilization Lagoon, Hydrodynamics, Dead Zones, Camber Curve, Screens

\section{Introduction}

Natural treatment systems, such as stabilization lagoon systems and wetlands either natural or artificial, represent a very useful alternative to being environmen- 
tally friendly systems, as well as being an economic option due to low operating and maintenance costs [1]. They are ideal to be implemented in places where there is not a large population or in rural areas, which makes the construction of conventional wastewater treatment plants difficult [2] [3] [4]. Stabilization lagoons aim to treat wastewater mainly from domestic, municipal and industrial sources [5] and also meet quantitative parameters, set by regulations in each country that allows their discharge into the receiving environment without causing environmental problems [6]. Stabilization lagoons are classified according to nature of biological activity that is carried out: aerobic, anaerobic and facultative [7] [8] [9]. Lagoons systems are usually constructed as the final stage of treatment of previous depuration systems, such as activated sludge, methods that replace chlorination, being the most common disinfection method in these systems [8] [10].

A particular case of stabilization lagoons is maturation lagoons; main functions are: 1) nitrification of ammoniac nitrogen, 2) nutrient removal and 3) clarification of effluent [11] [12]. The case study in this journal is a maturation lagoon system with screens which are constructed in Autonomous Metropolitan University-Azcapotzalco in Mexico City, like a pilot system to be used in mainly rural zones, where they design screens to approximate the flow of water to a piston model [13], improving the hydraulic retention times, on the other hand, to achieve an optimum treatment efficiency.

To avoid short circuits and dead zones, curved shapes with slope were designed in every channel change, which also generated more homogeneous flow. In order to achieve this, a study of hydrodynamic was carried out with IBER Software considering two periods of sampling: winter and spring, taking into account hydraulic flow velocities in each channel, and Froude number for ratio of inertia forces and gravity forces acting on water flow. In order to analyze the behavior in curves shapes with slope, a monitoring parameter of total solids in each channel was used. So as to determine efficiency of screens and curves in lagoon system: temperature, $\mathrm{pH}$, conductivity, dissolved oxygen (DO), chemical oxygen demand (COD), biochemical oxygen demand (BOD), total solids suspended (TSS), hardness and alkalinity were monitored.

\section{Materials and Methods}

In order to complete municipal wastewater treatment of a horizontal flow subsurface wetland for rural areas [14] a pilot lagoon system in Autonomous Metropolitan University-Azcapotzalco located in Mexico City was built. System measure $12.15 \mathrm{~m}$ long, $8 \mathrm{~m}$ wide, and $0.70 \mathrm{~m}$ high, divided into 7 channels with 6 screens built with light porous block, whose purpose is to fix bacterial film on the walls [15]. The main purpose of wetland-maturation lagoon system is to obtain quality water at least for agricultural irrigation. Figure 1 shows a diagram of wastewater treatment system which is fed by a primary treatment plant near the Campus and from wastewater of University. Figure 1 corresponds to pre-treatment system diagram with an average input of $5667 \pm 0.182 \mathrm{mg} / \mathrm{L}$ of TSS, $654.86 \pm$ $32.55 \mathrm{mg} / \mathrm{L}$ of BOD and $1064.48 \pm 44.85 \mathrm{mg} / \mathrm{L}$ of COD in winter, $4.176 \pm 0.164$ 
(a) Pre-treatment system

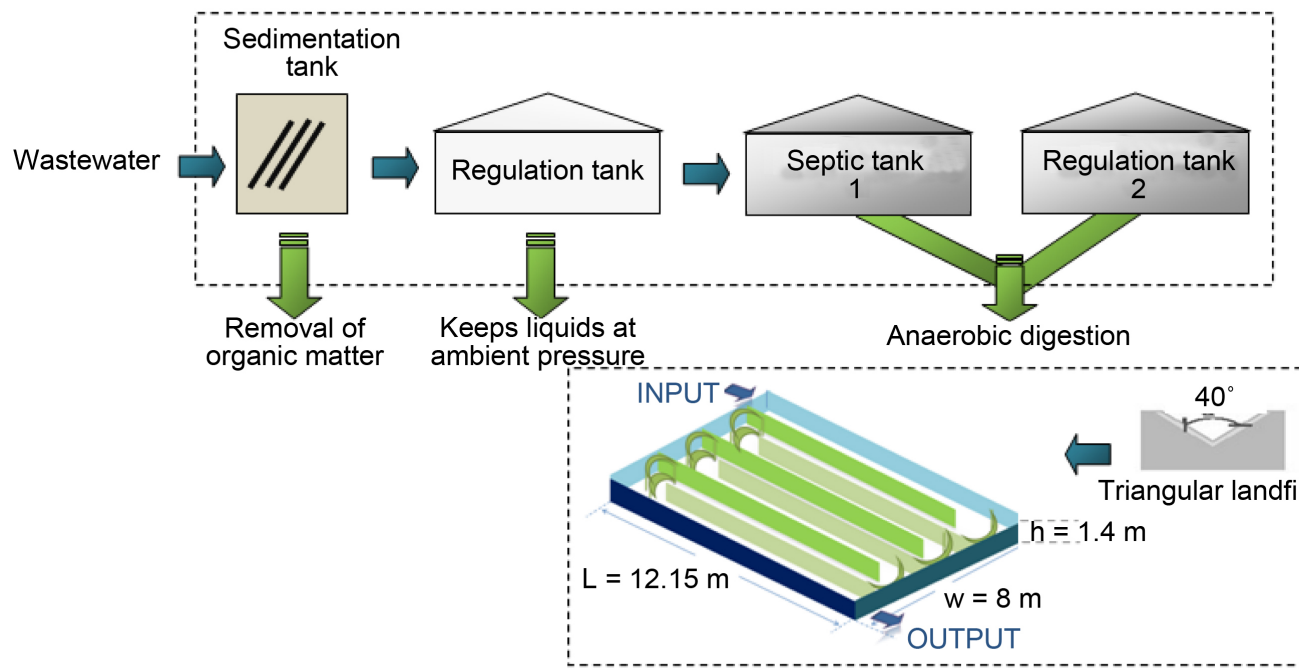

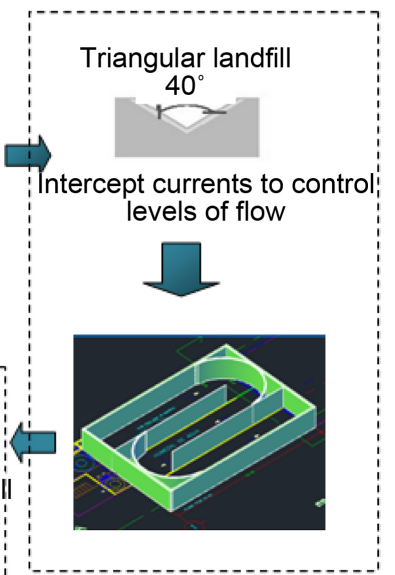

(b) Wetland system

(c) Maturation lagoon system

Figure 1. Diagram of natural treatment system (a) Pre-treatment system, (b) Wetland system, (c) Maturation lagoon system.

$\mathrm{mg} / \mathrm{L}$ of TSS, $1176.96 \pm 53.85 \mathrm{mg} / \mathrm{L}$ of BOD and $1923.13 \pm 81.66 \mathrm{mg} / \mathrm{L}$ of COD in spring.

Hydraulic previous consisting of an anaerobic pre-treatment system, Figure 1(a), where wastewater passes to two grids allowing retain sand and/or coarse settle able solids; after this water passes a regulation tank where it is accumulates and flow rate is controlled for system rest, next step is to bring water to two serially septic tanks where anaerobic digestion is performed to remove a portion of organic matter; for finally the wastewater enters to wetland through 12 water shedders in triangular form for influent and a design flow $Q$ of $2 \mathrm{~L} / \mathrm{s}$. Figure 1 (a) corresponds to the wetland, where it was entered with $1728 \pm 0.048 \mathrm{mg} / \mathrm{L}$ of TSS, $364.88 \pm 14.99 \mathrm{mg} / \mathrm{L}$ of BOD and COD $568.35 \mathrm{mg} / \mathrm{L} \pm 18.58 \mathrm{mg} / \mathrm{L}$ in winter and $1528 \pm 0.055 \mathrm{mg} / \mathrm{L}$ of TSS, $560.38 \pm 20.57 \mathrm{mg} / \mathrm{L}$ BOD and 987, $112 \pm 51.77$ $\mathrm{mg} / \mathrm{L}$ COD in spring. In Figure 1 (c) the lagoon system with screens is presented, which completes the study treatment presented in this article.

\subsection{Water Sampling in the Lagoon System}

Figure 2(a) shows an overview of the lagoon system with screens and curved shapes. Figure 2(b) shows a schematic with 21 sampling sites, where site 1 is located at the entrance in lagoon system and site 21 is located at output in lagoon system.

Lagoon system is built with porous block, as it aims to build such facilities in rural areas for economic reasons and on the other hand it is to take advantage of porosity of the material for fixing bacterial film.

Sampling in each sites selected was monitored for 2 periods: winter and spring 2016, at the same time from 10:00 a.m. to 4:00 p.m. with the purpose of ensure microbial activity. Sampling was carried out at a regular depth of $25 \mathrm{~cm}$ with kind bailer samplers at 13:00 hours. 


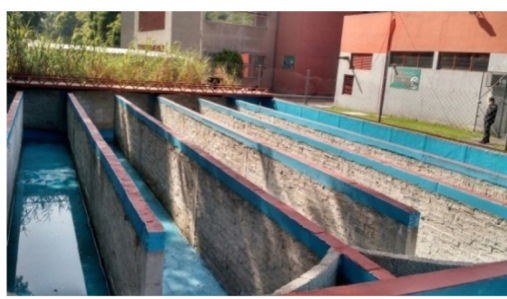

(a)

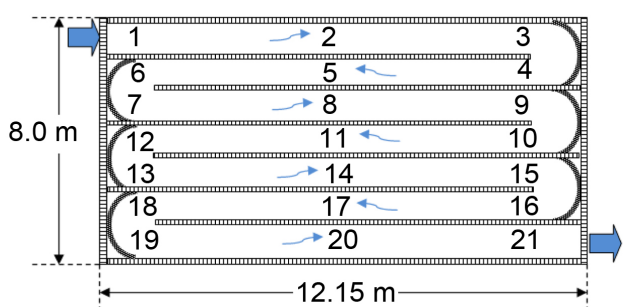

(b)

Figure 2. (a) Lagoon system, (b) Location of sampling sites in maturation lagoon.

\subsection{Measures in Situ}

In order to determine the behavior of lagoon system as a function of parameters: temperature, $\mathrm{pH}$, conductivity, redox potential (ORP), dissolved oxygen (DO), total solids suspended (TSS) sites in seven mentioned channels were defined. $\mathrm{pH}$ was determined according to the NMX-AA-008-SCFI-2000 [16] standard, while temperature was determined according to NMX-AA-007-SCFI-2000 [17]. For each parameter a Hanna model HI 1618 sensor was used, with a Hanna HI98150 interface. Finally, for conductivity and ORP measurements a LabQuest Vernier Interface system with its respective sensors was used.

\subsection{Ex Situ Measures}

Alkalinity [18] and Hardness was determined [19]. The COD was determined by Hach method with a Hanna brand reactor model HI-839800 and a UV/visible spectrophotometer DR/2400 brand Hach. To obtain total solids (TSS) the technique of standard methods [20] was followed. The volume collected in all cases was one litter in Nalgen containers, kept under refrigeration at $4^{\circ} \mathrm{C}$. In situ measurements, for maximum dissolved oxygen concentration, corresponding to a maximum microbiological activity was performed in all samples at 1:00 p.m. [21]. All determinations were performed on an average of two samplings per week per season (winter and spring).

\subsection{Design of Landfills for Incoming Water to the Lagoon}

It was important to consider optimization and homogenization of water flow in the input of lagoon system, for which landfills were designed, using Thomson Equation (1) for triangular landfills [22].

$$
\sqrt[5 / 2]{\frac{1.40}{2}}=H \text { for landfills of } 90^{\circ}
$$

where:

$Q=$ Flow $\left(\mathrm{m}^{3} / \mathrm{s}\right)$.

$H=$ Water from the landfill (m).

Flow rate that enters in lagoon system from wetland was $Q=2 \mathrm{~L} / \mathrm{s}$, and for design of landfill was considered from Thomson Table [22] a coefficient of 1.4, obtaining a total load $\mathrm{H}$ equal to $0.867 \mathrm{~cm}$, which was divided among 12 landfills, so that $H /$ landfill of $0.072 \mathrm{~cm}$ was obtained (Figure 3 ). 


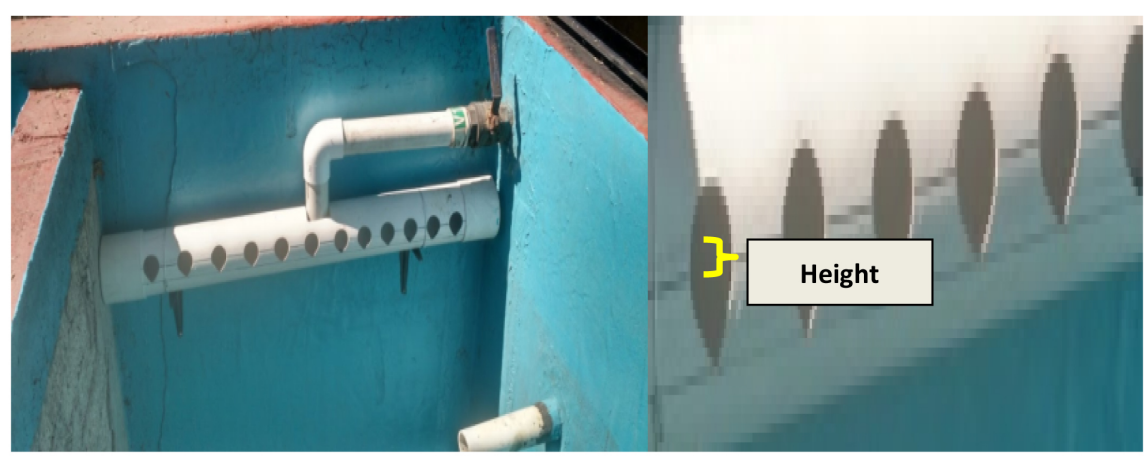

Figure 3. Landfills for entry of water from the wetland.

\subsection{Modeling Using IBER Software}

For hydrodynamic study in lagoon system, IBER software was used [23] which is a numerical model of simulation of free-flow in non-permanent regime and of environmental processes in fluvial hydraulics. Application of IBER covers fluvial hydrodynamics, flood zones evaluation, transport of suspended material and aquatic flows calculation. Hydrodynamic module for two dimensions was used for this study, where conservation equations of mass and momentum were solved.

$$
\begin{aligned}
& \frac{\partial h}{\partial t}+\frac{\partial h U_{x}}{\partial x}+\frac{\partial h U_{y}}{\partial y}=M_{s} \\
& \frac{\partial h U_{x}}{\partial t}+\frac{\partial h U_{x}^{2}}{\partial x}+\frac{\partial h U_{x} U_{y}}{\partial y} \\
& =-g h \frac{\partial Z_{s}}{\partial x}+\frac{\tau_{s, x}}{\rho}-\frac{\tau_{b, x}}{\rho}-\frac{g}{\rho} \frac{h^{2}}{2} \frac{\partial \rho}{\partial x}+2 \Omega \sin \lambda U_{y}+\frac{\partial h \tau_{x x}^{e}}{\partial x}+\frac{\partial h \tau_{x y}^{e}}{\partial y}+M_{x} \\
& \frac{\partial h U_{y}}{\partial t}+\frac{\partial h U_{x} U_{y}}{\partial x}+\frac{\partial h U_{y}^{2}}{\partial y} \\
& =-g h \frac{\partial Z_{s}}{\partial y}+\frac{\tau_{s, y}}{\rho}-\frac{\tau_{b, y}}{\rho}-\frac{g}{\rho} \frac{h^{2}}{2} \frac{\partial \rho}{\partial y}-2 \Omega \sin \lambda U_{x}+\frac{\partial h \tau_{x y}^{e}}{\partial x}+\frac{\partial h \tau_{y y}^{e}}{\partial y}+M_{y}
\end{aligned}
$$

where:

$h=$ depth;

$U_{x}, U_{y}=$ Horizontal velocities averaged in depth;

$G=$ Acceleration of gravity;

$Z_{s}=$ Free surface elevation;

$\tau_{s}=$ Friction in free surface due to the friction produced by wind;

$\rho=$ Density of water;

$\Omega=$ Angular velocity of rotation of the earth;

$\Lambda$ = Latitude of the point considered;

$\tau_{x x}^{e}, \quad \tau_{x y}^{e}, \quad \tau_{y y}^{e}=$ Horizontal effective tangential tensions;

$M_{s}, M_{x}, M_{y}=$ Source/sink sum of mass and moment, through which the modelling is performed.

\section{Results}

The variation of parameters: temperature, $\mathrm{pH}$, conductivity, hardness and alka- 
linity during two sampling periods are presented in Table 1, corresponding to spring and winter. It is observed that values of Temperature did not vary significantly and ranged from $17^{\circ} \mathrm{C}$ to $24^{\circ} \mathrm{C}$, adequate values for development of photosynthetic activity [24]. In terms of $\mathrm{pH}$, a decrease was observed in both periods. Conductivity determination is related to the presence of ions in water [15] values along the system are presented in Table 1 , a decrease in values as you move from one channel to another is observed. However as in COD when entering water flow to curves shapes with slope an increase in its concentration is noticed, due to a reduction of velocity generated by slope, thus allowing ions concentration and therefore conductivity tends to increase. At system output with an increase in velocity, a homogeneous distribution of ions is observed. In addition a dilution and/or adsorption of ions are able to results in site 21 lower concentrations than first channels. As for the Hardness of water in each channel during two sampling seasons, an increase mainly in calcium ions at curves input is observed, behavior that coincides with conductivity variation. Same effect on conductivity variation again presents, water in all sampling sites until system output,

Table 1. Physicochemical parameters variation in lagoon system with screens.

\begin{tabular}{|c|c|c|c|c|c|c|c|c|c|}
\hline \multirow[t]{2}{*}{ Site } & \multicolumn{2}{|c|}{$\begin{array}{c}\text { Temperature } \\
{ }^{\circ} \mathrm{C}\end{array}$} & \multicolumn{2}{|c|}{$\mathrm{pH}$} & $\begin{array}{l}\text { Conductivity } \\
\mu \mathrm{S} / \mathrm{cm}\end{array}$ & \multicolumn{2}{|c|}{$\begin{array}{c}\text { Hardness } \\
\text { Eq. } \mathrm{CaCO}_{3}\end{array}$} & \multicolumn{2}{|c|}{$\begin{array}{l}\text { Alkalinity } \\
\text { Eq. } \mathrm{CaCO}_{3}\end{array}$} \\
\hline & Winter & Spring & Winter & Spring & Winter & Winter & Spring & Winter & Spring \\
\hline 0 & $17.80 \pm 0.73$ & $19.80 \pm 0.76$ & $7.89 \pm 0.20$ & $7.87 \pm 0.31$ & $319.60 \pm 11.92317 .90 \pm 8.17$ & $136.22 \pm 5.15$ & $141.12 \pm 3.88$ & $287.00 \pm 7.03$ & $277 \pm 8.93$ \\
\hline 1 & $18.20 \pm 0.695$ & $20.10 \pm 0.62$ & $7.87 \pm 0.30$ & $7.83 \pm 0.30$ & $319.10 \pm 13.11316 .83 \pm 7.86$ & $132.43 \pm 6.03$ & $138.43 \pm 4.78$ & $281.00 \pm 8.33$ & $272 \pm 10.91$ \\
\hline 3 & $18.80 \pm 0.70$ & $20.60 \pm 0.88$ & $7.86 \pm 0.21$ & $7.80 \pm 0.28$ & $319.40 \pm 15.11316 .86 \pm 9.47$ & $132.03 \pm 4.33$ & $138.03 \pm 3.96$ & $282.00 \pm 8.49$ & $273 \pm 8.93$ \\
\hline 4 & $19.40 \pm 0.74$ & $20.90 \pm 0.85$ & $7.84 \pm 0.31$ & $7.72 \pm 0.27$ & $317.12 \pm 9.16314 .20 \pm 12.60$ & $126.60 \pm 4.34$ & $125.60 \pm 4.05$ & $278.00 \pm 7.42$ & $271 \pm 8.63$ \\
\hline 5 & $19.60 \pm 0.83$ & $21.30 \pm 0.66$ & $7.85 \pm 0.24$ & $7.74 \pm 0.31$ & $315.50 \pm 8.77314 .00 \pm 8.71$ & $123.55 \pm 4.07$ & $121.55 \pm 3.59$ & $280.00 \pm 7.90$ & $268 \pm 10.72$ \\
\hline 6 & $19.90 \pm 0.83$ & $21.80 \pm 0.66$ & $7.85 \pm 0.26$ & $7.69 \pm 0.26$ & $317.22 \pm 9.67315 .87 \pm 9.19$ & $126.38 \pm 5.18$ & $126.38 \pm 5.05$ & $277.00 \pm 8.54$ & $271 \pm 9.35$ \\
\hline 8 & $20.50 \pm 0.90$ & $22.60 \pm 0.73$ & $7.78 \pm 0.31$ & $7.68 \pm 0.30$ & $317.56 \pm 10.22315 .00 \pm 9.92$ & $115.45 \pm 4.75$ & $117.25 \pm 3.12$ & $266.00 \pm 8.28$ & $263 \pm 10.58$ \\
\hline 9 & $21.30 \pm 0.80$ & $22.90 \pm 1.11$ & $7.76 \pm 0.26$ & $7.63 \pm 0.28$ & $317.81 \pm 12.24315 .37 \pm 12.84$ & $117.35 \pm 4.55$ & $120.35 \pm 4.87$ & $268.00 \pm 7.42$ & $265 \pm 9.86$ \\
\hline 10 & $21.70 \pm 0.88$ & $23.20 \pm 0.80$ & $7.74 \pm 0.25$ & $7.69 \pm 0.24$ & $317.43 \pm 11.85314 .37 \pm 9.97$ & $102.73 \pm 4.23$ & $118.73 \pm 4.55$ & $264.00 \pm 8.32$ & $262 \pm 10.17$ \\
\hline 11 & $22.30 \pm 0.83$ & $23.60 \pm 0.98$ & $7.73 \pm 0.30$ & $7.65 \pm 0.30$ & $316.56 \pm 8.64314 .00 \pm 8.73$ & $102.18 \pm 4.17$ & $112.18 \pm 3.20$ & $260.00 \pm 7.23$ & $256 \pm 10.56$ \\
\hline 12 & $22.50 \pm 0.83$ & $24.70 \pm 1.13$ & $7.73 \pm 0.22$ & $7.67 \pm 0.24$ & $317.18 \pm 13.13314 .56 \pm 7.61$ & $104.95 \pm 3.29$ & $114.95 \pm 3.98$ & $263.00 \pm 8.44$ & $259 \pm 8.97$ \\
\hline 13 & $22.70 \pm 1.06$ & $25.60 \pm 0.88$ & $7.69 \pm 0.30$ & $7.64 \pm 0.27$ & $316.64 \pm 10.52313 .78 \pm 9.95$ & $103.13 \pm 3.04$ & $110.13 \pm 3.44$ & $261.00 \pm 6.95$ & $255 \pm 8.14$ \\
\hline 14 & $22.30 \pm 0.98$ & $25.20 \pm 0.95$ & $7.65 \pm 0.35$ & $7.62 \pm 0.31$ & $317.55 \pm 11.84313 .32 \pm 13.38$ & $100.30 \pm 2.68$ & $100.30 \pm 4.12$ & $257.00 \pm 7.37$ & $252 \pm 10.15$ \\
\hline 15 & $21.70 \pm 0.72$ & $25.40 \pm 1.08$ & $7.67 \pm 0.30$ & $7.66 \pm 0.27$ & $318.87 \pm 9.31313 .98 \pm 14.03$ & $103.53 \pm 3.39$ & $111.53 \pm 3.32$ & $260.00 \pm 8.47$ & $258 \pm 11.40$ \\
\hline 16 & $21.50 \pm 0.72$ & $24.70 \pm 0.97$ & $7.63 \pm 0.33$ & $7.68 \pm 0.30$ & $317.59 \pm 10.32312 .86 \pm 10.97$ & $101.70 \pm 4.07$ & $109.70 \pm 4.58$ & $256.00 \pm 7.91$ & $253 \pm 9.41$ \\
\hline 17 & $20.60 \pm 0.88$ & $23.80 \pm 0.82$ & $7.66 \pm 0.22$ & $7.65 \pm 0.25$ & $314.87 \pm 12.69312 .27 \pm 10.71$ & $99.80 \pm 3.54$ & $100.80 \pm 4.12$ & $250.00 \pm 7.13$ & $251 \pm 9.75$ \\
\hline 19 & $19.60 \pm 0.69$ & $22.20 \pm 0.90$ & $7.62 \pm 0.33$ & $7.69 \pm 0.30$ & $316.38 \pm 9.08 \quad 312.30 \pm 9.09$ & $100.80 \pm 3.84$ & $102.80 \pm 3.27$ & $247.00 \pm 7.51$ & $250 \pm 8.87$ \\
\hline 20 & $19.20 \pm 0.62$ & $22.70 \pm 0.88$ & $7.63 \pm 0.34$ & $7.71 \pm 0.37$ & $314.82 \pm 9.70312 .00 \pm 11.13$ & $90.68 \pm 2.80$ & $99.97 \pm 40.29$ & $241.00 \pm 6.63$ & $245 \pm 9.46$ \\
\hline 21 & $18.30 \pm 0.74$ & $20.30 \pm 0.64$ & $7.58 \pm 0.20$ & $7.65 \pm 0.24$ & $311.77 \pm 7.98310 .72 \pm 11.66$ & $90.28 \pm 2.62$ & $97.28 \pm 3.12$ & $238.00 \pm 5.55$ & $242 \pm 7.72$ \\
\hline
\end{tabular}


resulted with values of 75 - 150, reason why it is considered Moderately Hard (MD) according criteria of international hardness [25]. Table 1 also shows alkalinity variation along the system, $\mathrm{pH}$ values fluctuated in two sampling periods between 7.9 - 7.5 [25] region that covers the predominance of bicarbonates, therefore alkalinity belongs to $\mathrm{HCO}_{3}^{-}$. Behavior in terms of distribution in different channels is consistent with conductivity and hardness.

\subsection{Total Solids Suspended (TSS) Variation}

In Figure 4, it is observed a higher concentration of solids $(\mathrm{mg} / \mathrm{L})$ in every channel change (3 - 4, 6 - 7, 9 - 10, 12 - 13, 15 - 16 and 18 - 19), due to the entrance of water flow in each curve with slope, phenomenon that occurred in both periods.

Overall, a tendency to decrease in concentration of TSS was observed, being scarce on departure at exit of lagoon system, which indicates a homogeneous sedimentation process along each channel.

\subsection{Dissolved Oxygen (D0) Variation}

Dissolved Oxygen (DO) variation in lagoon system is observed in Figure 5. It is

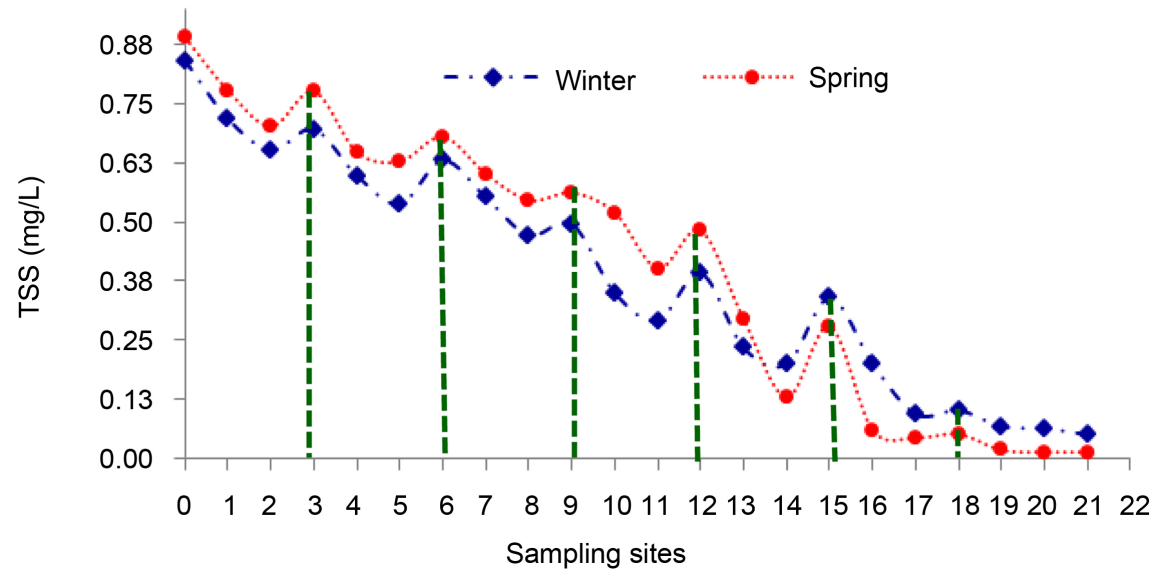

Figure 4. Total Solids Suspended (TSS) variation in lagoon system in two seasons.

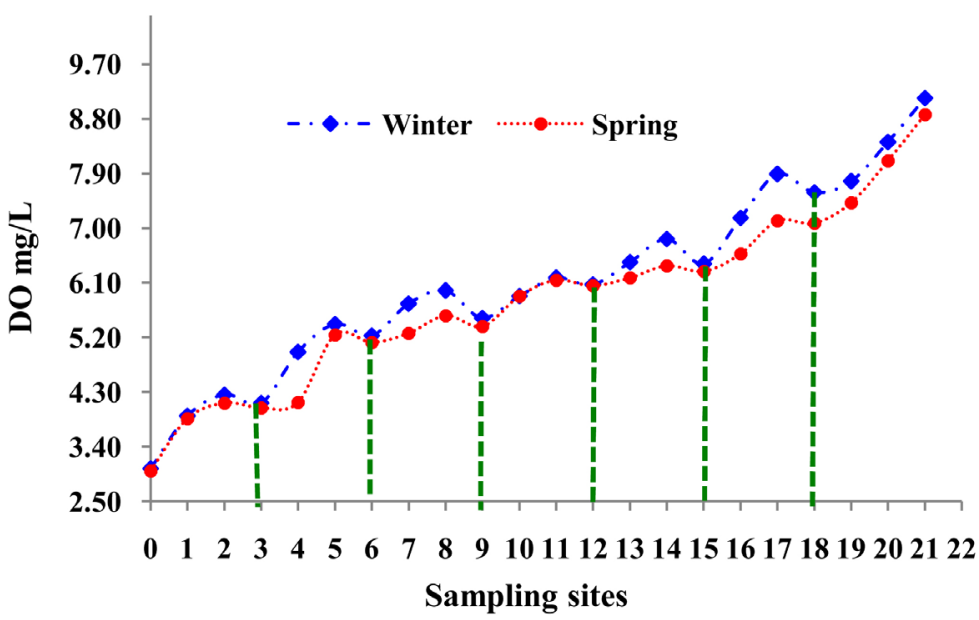

Figure 5. Dissolved Oxygen variation in lagoon system in two seasons. 
important to mention that water which entering in system, comes from a treatment sub-surface wetland of horizontal flow [14] later enters in lagoon through 12 landfills, where flow is distributed and conducted to first channel in lagoon system, a jump of $50 \mathrm{~cm}$ height allowing aeration of water is produced. DO oscillate in values $3.04 \pm 0.144 \mathrm{mg} / \mathrm{L}$ at the entrance of first channel during the winter and $3.00 \pm 0.132$ in spring. DO concentration increases as water flow along each channel is advanced, later it is reduce to input of each curve with slope, and is indicated by vertical dotted lines.

Finally, the concentration improves at the exit of each curve and during straight sections. DO behavior is consistent with the redox potential (ORP) (Figure 6) and COD (Figure 7). Oxygenation was better in winter due to presence of algae and also due to lower evapotranspiration. In spring, oxygenation was lower despite presence of algae and an increase in temperature was observed. Due to action of wind and rain season during April and May respectively, there was a significant fall of leaves, reason for which degradation of organic matter could have consumed part of oxygen. Overall a decrease of DO is observed, it was not so abrupt in first channels, and in spite of this the behavior profiles were retained.

\subsection{Redox Potential Variation (ORP)}

In Figure 6, it was observed that ORP approached increasingly positive values as the flow advanced from channel to channel, behavior that coincided with DO variation. In winter, the ORP presented values more negative than in the spring, but from site 5 (corresponding to channel 2) acquired values slightly more positive than those of spring, behavior that lasted until the exit of the system.

It is also observed that at site 1 (entrance to the system) is the site with the most negative value in both stations, as the flow advances along the channels, an improvement in conductivity is observed, behavior that coincides with the Improvement of DO and COD. It can also be observed that at the beginning of each ORP curve it acquired negative values.

\subsection{Biochemical Oxygen Demand (BOD)}

Figure 8 shows results using the two graphs according two stations, a very marked trend of decreasing in BOD was observed. At entrances of curves shapes with

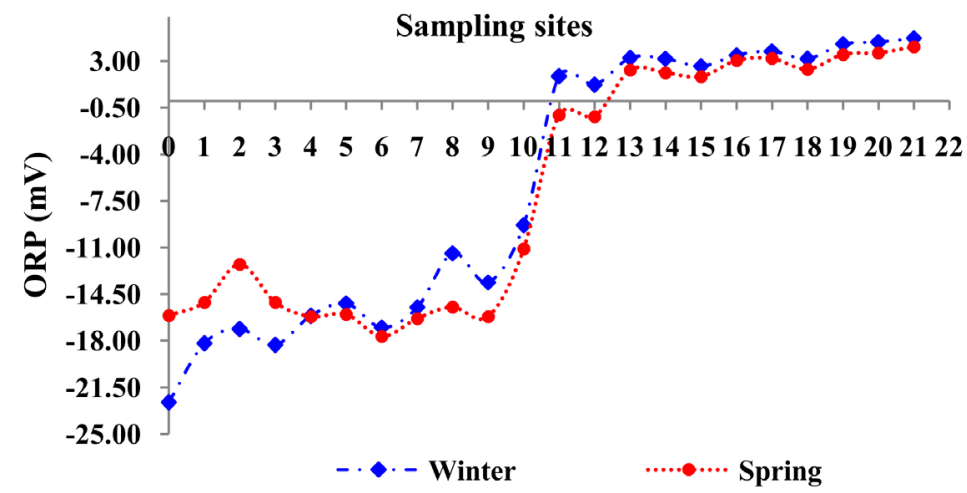

Figure 6. ORP variation in lagoon system in two seasons. 


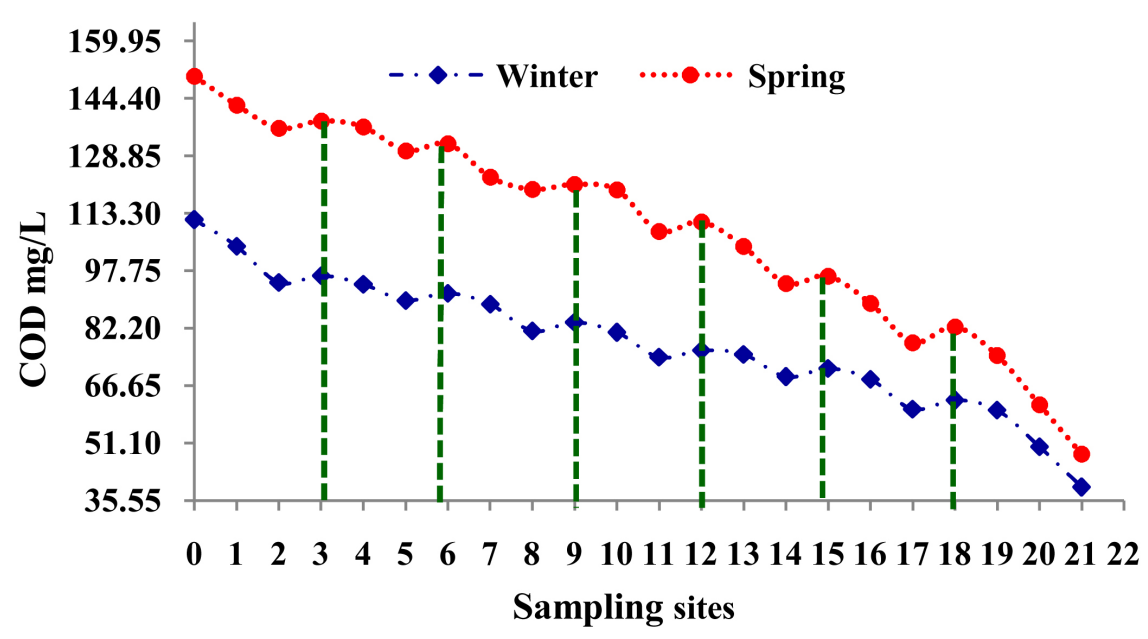

Figure 7. COD variation in lagoon system in two seasons.

slope, BOD increased, due to the fact that there was more accumulation of biodegradable material, the degradation was increasing until its decrease in the output of lagoon system.

\subsection{Analysis of Chemical Oxygen Demand (COD)}

COD is a representative measure of organic contamination in an effluent, parameter which will be controlled within the different discharge regulations. Figure 7 presents results of $\mathrm{COD}$ as a parameter for monitoring the degradation of organic material, both biodegradable and non-biodegradable in the different channels along the lagoon system. There was a general trend of decreasing COD along the channels at both stations. At the beginning of each banked curve a higher concentration of COD was presented, where more oxygen was required for oxidation of organic matter and it is related with ORP values because these parameters are closely related.

\subsection{Modelling Results with Software IBER}

In Figure 9(a), the result of modeling with IBER software is presented, observing a velocity distribution in different sections of lagoon system, identifying the variation of water flow with different colors: light blue means a uniform flow and changes to dark blue in external curve section, where the flow decreases its velocity. In internal curve section there is an increase that impels it to exit of the curve, stabilizing this flow along of channel. The phenomenon is repeated in each curve until last channel, where flow acquires a greater velocity until output of lagoon, which is represented with yellow-green color (Figure 9(a)). Note the almost yellow color where flow is virtually free.

Froude number was determinate, which relates forces of inertia and gravity, implicitly considering velocity and hydraulic gradient at each point of path the water flow, evaluating type of regime. Figure 9(b) shows increasing Froude number as the water flow increased in each channels, ending with a tendency toward a critical regime in the seventh channel. It can also be observed, as in velocity case 


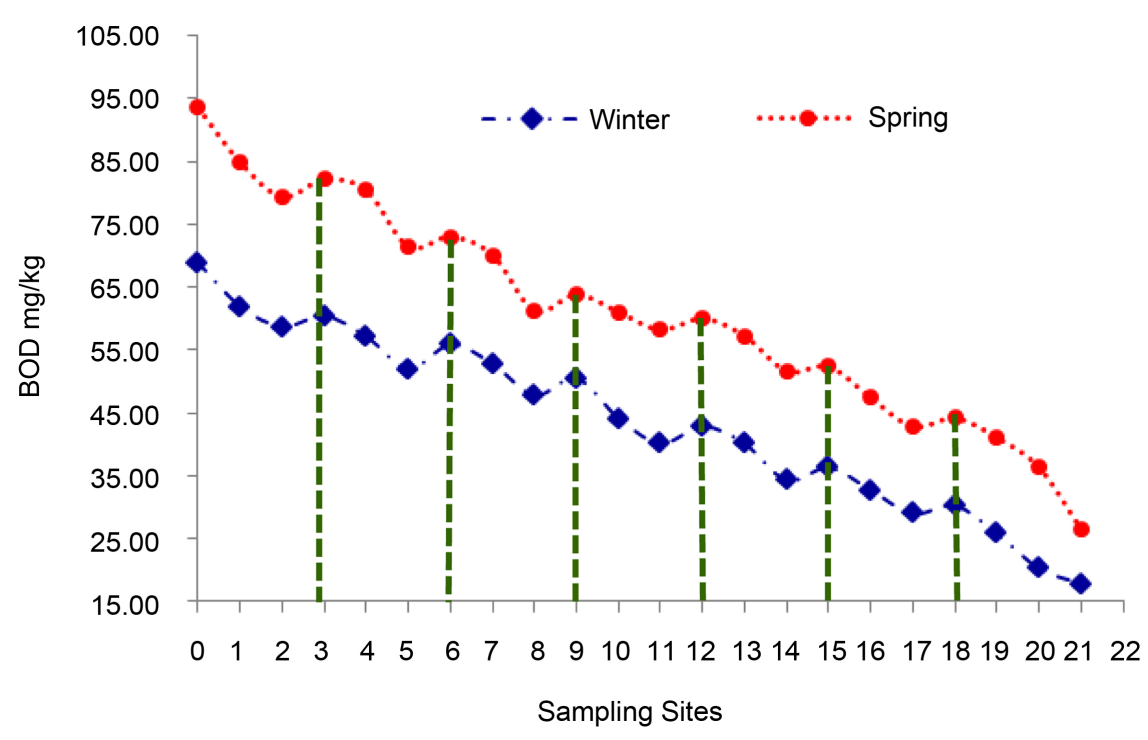

Figure 8. BOD variation in lagoon system in two seasons.

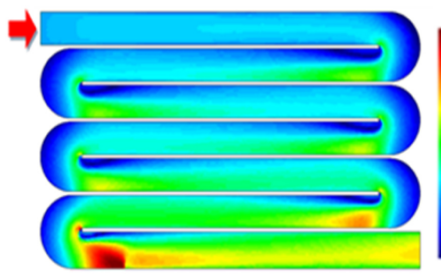

(a)

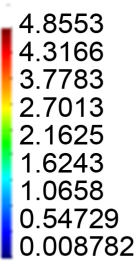

0.0087821

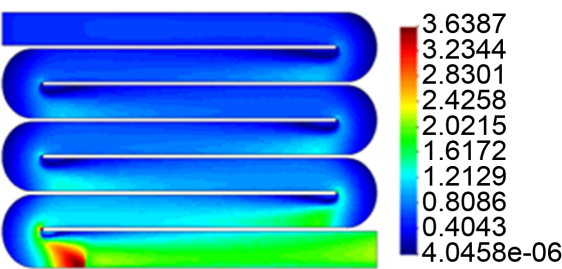

(b)

Figure 9. (a) Velocity variation, (b) Modeling Froude number, both with IBER software.

that increase at the end of each of curves, which is due to hydraulic jump caused by slope change in curves. A change in critical regime was presented, for example, in changes in slope. The flow in critical regime (or in its environs) was unstable [14].

\subsection{Transport of Total Suspended Solids with IBER}

This software was also used to model TSS transport in the lagoon system (Figure 10). The concentration of TSS in water is corresponding to field measured values which were introduced in the software. The results indicate that the highest concentration occurred in the first channel (red color), although it seems that before the entrances to the curves the TSS tend to concentrate, this can be due to reduction velocity. In the other channels also there is a drag of TSS, always concentrating at the entrance of each curve, until concentration decreases. It is important to note with this model that in zones of the curves, blue color is homogeneous, which indicates that there are no short circuits, therefore there are no "dead zones" and the hydraulic flow improves significantly.

\subsection{System Efficiency}

Table 2 summarizes BOD and COD values as parameters for efficiency follow 


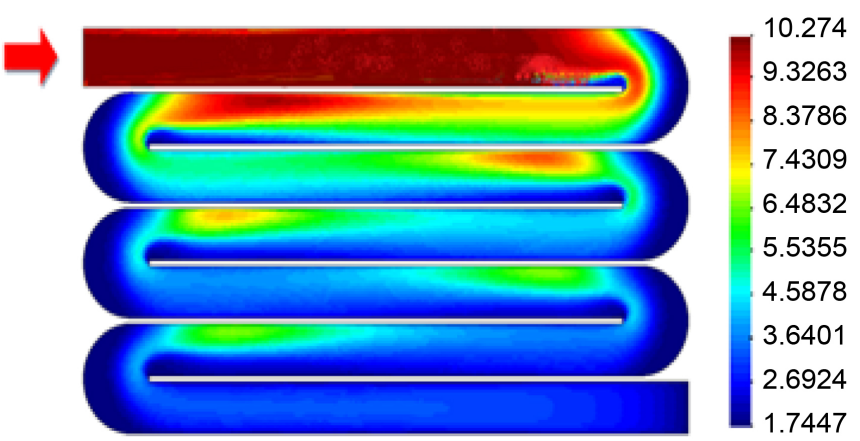

Figure 10. Transport of suspended solids.

Table 2. Efficiency of treatment by the lagoon system with screens and curve shapes with slope.

\begin{tabular}{cccccc}
\hline \% BOD & Winter & Spring & \% COD & Winter & Spring \\
\hline First channel & 12.34 & 12.20 & First channel & 13.53 & 8.05 \\
Second channel & 2.31 & 9.15 & Second channel & 2.60 & 9.52 \\
Third channel & 4.42 & 8.96 & Third channel & 5.48 & 1.56 \\
Fourth channel & 2.92 & 1.67 & Fourth channel & 6.02 & 5.77 \\
Fifth channel & 9.50 & 8.51 & Fifth channel & 5.40 & 8.32 \\
Sixth channel & 7.42 & 6.81 & Sixth channel & 28.33 & 7.18 \\
Seventh channel & 26.17 & 32.99 & Seventh channel & 30.95 & 38.49 \\
Input-output & 74.11 & 71.69 & Input-output & 64.90 & 67.99 \\
\hline
\end{tabular}

up in each channel. Regarding BOD in the first and seventh channels, the best efficiency was observed in the sixth and seventh channels for COD.

Finally in Table 3, efficiency of all system is shown, considering Figure 1. In pre-treatment, practically the same efficiency was achieved in two seasons with a little higher value in winter for the three parameters. In the wetland, TSS concentration was slightly higher in winter, however BOD and COD were better in spring, possibly the rise of temperature improved the ability of microorganisms to degrade MO.

In case of lagoon system, the treatment for TSS was better in winter, because fewer solids were introduced in wetland. The BOD was slightly better in winter, where the flow velocity can be influenced by the curved forms of each channel that avoid short circuits and therefore dead zones, same can be said of COD.

\section{Conclusions}

Design of 7 screens in lagoon helped to approximate the total water flow to a piston flow, which was optimized by the slopes in curves that induced to cross to the flow in sections where tangential forces were distributed evenly, avoiding thus presence of dead zones, short circuits and dispersed flows.

In addition, a good distribution of the hydraulic flow was achieved, which was demonstrated through behavior of DO, OPR, TSS, BOD and COD, as shown in graphs. With IBER software, it was possible to obtain velocity distribution and 
Table 3. Efficiency at each treatment stage for season and efficiency in all systems.

\begin{tabular}{|c|c|c|c|c|c|c|}
\hline \multicolumn{7}{|c|}{ Pre-treatment system } \\
\hline & \multicolumn{3}{|c|}{ Winter } & \multicolumn{3}{|c|}{ Spring } \\
\hline Parameter (mg/L) & Input & Output & \% Efficiency & Input & Output & \% Efficiency \\
\hline TSS & 5.667 & 1.728 & 69.51 & 4.176 & 1.528 & 63.41 \\
\hline BOD & 654.86 & 398.77 & 39.11 & 1176.96 & 701.26 & 40.42 \\
\hline COD & 1064.48 & 568.13 & 46.63 & 1923.13 & 986.67 & 48.69 \\
\hline \multicolumn{7}{|c|}{ Treatment by wetland } \\
\hline & \multicolumn{3}{|c|}{ Winter } & \multicolumn{3}{|c|}{ Spring } \\
\hline Parameter $(\mathrm{mg} / \mathrm{L})$ & Input & Output & \% Efficiency & Input & Output & \% Efficiency \\
\hline TSS & 1.728 & 0.842 & 51.30 & 1.528 & 0.890 & 41.75 \\
\hline BOD & 398.77 & 68.921 & 82.72 & 701.26 & 93.581 & 86.66 \\
\hline $\mathrm{COD}$ & 568.13 & 111.50 & 80.37 & 986.66 & 150.03 & 84.79 \\
\hline \multicolumn{7}{|c|}{ Treatment by lagoon system } \\
\hline & \multicolumn{3}{|c|}{ Winter } & \multicolumn{3}{|c|}{ Spring } \\
\hline Parameter (mg/L) & Input & Output & \% Efficiency & Input & Output & \% Efficiency \\
\hline TSS & 0.842 & 0.051 & 93.94 & 0.890 & 0.014 & 51.30 \\
\hline BOD & 68.92 & 17.85 & 74.11 & 93.58 & 26.49 & 71.69 \\
\hline COD & 111.50 & 39.14 & 64.90 & 150.45 & 48.17 & 67.99 \\
\hline \multicolumn{7}{|c|}{ Total system treatment } \\
\hline & \multicolumn{3}{|c|}{ Winter } & \multicolumn{3}{|c|}{ Spring } \\
\hline Parameter (mg/L) & \multicolumn{3}{|c|}{ \% Efficiency } & \multicolumn{3}{|c|}{ \% Efficiency } \\
\hline TSS & \multicolumn{3}{|c|}{99.10} & \multicolumn{3}{|c|}{99.19} \\
\hline BOD & \multicolumn{3}{|c|}{97.27} & \multicolumn{3}{|c|}{97.75} \\
\hline COD & \multicolumn{3}{|c|}{96.32} & \multicolumn{3}{|c|}{91.52} \\
\hline
\end{tabular}

Froude number in different sections, also modelling the transport of TSS, which allowed knowing areas susceptible to TSS saturation. The slope change in curve reduces the bottom drag of sediments, producing a slight decrease in flow velocity, causing the total solids to be retained in pre-curve sections.

When analyzing removal rates of both the lagoon and entire treatment system, it was observed that lagoon system allowed completing the treatment in compliance with Mexican norm NOM-001-SEMARNAT-1996 of discharges and NOM-003SEMARNAT-1997 for agricultural water.

\section{References}

[1] Llagas, C., Wilmer, A. and Gómez, G. (2006) Design of Artificial Wetlands for Wastewater Treatment at the University National Mayor of San Marcos, Peru. Journal of Research Institute of the Faculty of Geological, Mining, Metallurgical and Geographical Engineering, 9, 85-96.

[2] Barrera, B., Barceló, Q., Vázquez, H. and Bussy, B. (2009) Physico-Chemical and Biological Characterization in Experimental Stabilization Ponds. AIDIS Journal of Engineering and Environmental Sciences: Research, Development and Practice, 1. http://www.journals.unam.mx/index.php/aidis/article/view/14387/13726 
[3] Dixon, W. and Chiswell, B. (1996) Review of Aquatic Monitoring Program Design. Water Research, 30, 1935-1948.

[4] Naddafi, K., Hassanvand, A.S., Dehghanifard, E., Faezi-Razi, D., Mostofi, S., Kasaee, N., Nabizadeh, R. and Heidari, M. (2009) Performance Evaluation of Wastewater Stabilization Ponds in Arak-Iran, Iran. Journal of Environmental Health Science \& Engineering, 6, 41-46.

[5] Barrera Bernal, C., Vázquez, G., Barceló Quintal, I. and Bussy, A. (2008) Microalgal Dynamics in Batch Reactors for Municipal Wastewater Treatment Containing Dairy Sewage Water. Water, Air and Soil Pollution, 190, 259-270. https://doi.org/10.1007/s11270-007-9598-3

[6] Mara, D. (2004) Domestic Wastewater Treatment in Developing Countries. Earthscan Publications, London.

[7] Yañez, C. (2000) Highlights in Design of Stabilization Lagoons. International Seminar on Wastewater Treatment, Division of Wastewater International Association of Sanitary and Environmental Engineering Porto Alegre, AIDIS, Brazil.

[8] Montalvo, S., Guerrero, L., Rivera, E., Boirja, R., Chica, A. and Martín, A. (2010) Kinetic Evaluation and Performance of Pilot-Scale Fed-Batch Aerated Lagoons Treating Winery Wastewaters. Bioresourse Technology, 101, 3452-3456.

[9] Pena, V. and Mara, D. (2004) Waste Stabilization Ponds. IRC International Water and Sanitation Centre.

http://www.bvsde.paho.org/bvsacd/cd27/ponds.pdf

[10] Kayombo, S., Mbwette, T., Katima, J., Ladegaard, N. and Jørgensen, S. (2005) Waste Stabilization Ponds and Constructed Wetlands Design Manual. United National Environment Programme, Osaka, Japan.

[11] Rivas, H. (2013) Kinetic Constants Determination for Design and Optimization of a Combined System Wetland-Maturation Lagoon with a Climatic Condition in Mexico City. Thesis PhD, UAM Azcapotzalco, Mexico.

[12] Barceló, Q., García, M., López, C., Osornio, B., Hernández, M., García, A. and Solís, C. (2015) Design of Canals in a Ripening Lagoon in the UAM Azcapotzalco to Avoid Dead Zones. 2nd Amica Congress 2015, Congress conducted in Puebla, Puebla, Mexico.

[13] Garcia, M., Barceló, Q., Lopez, C., Osornio, B. and Beltrán, R. (2016) Efficiency of Wastewater Treatment by a Pilot Lagoon System with Screens and Camber Curves. 13 th IWA Specialized Conference on Small Water and Wastewater Systems \& 5 th IWA Specialized Conference on Resources-Oriented Sanitation, Congress Conducted in Athens, Greece.

[14] Osornio, B., Barceló, Q., López, C., Rivas, H. and García, M. (2016) Obtaining Hydrodynamic, Physicochemical and Chemical Parameters for the Efficient Operation of Municipal Wastewater Treatment in the Wetland System in UAM Azcapotzalco. IWA Poland IWA Specialist Conference on Wetland Systems for Water Pollution Control, ECS, Congress conducted in Gdańsk, Poland.

[15] Rosas, A., Barceló, Q., Bussy, B. and López, G. (2010) Technical Proposal on the Treatment of the Influent of José Antonio Alzate Dam, through an Aerobic Lagoon System. Engineering Research and Technology, 11, 113-125.

[16] NMX-AA-008-SCFI-2000. Mexican Standard, Water Analysis Determination of pH-Test.

[17] NMX-AA-007-SCFI-2000. Mexican Standard, Water Analysis Determination of Temperature.

[18] APHA-AWWA-WEF (2005) Standard Methods for the Examination of Water and Wastewater. 21th Edition, New York, Alkalinity Method 2320, 2-27 a 2-29.

[19] APHA-AWWA-WEF (2005) Standard Methods for the Examination of Water and Wastewater. 25th Edition, New York Hardness, Method 2340B, 2-37.

[20] APHA-AWWA-WEF (2005) Standard Methods for the Examination of Water and Wastewater. 21th Edition. New York, Total Solids Suspended, Method 2540 D, 2-55 
a 2-59.

[21] Romero, R. (2005) Sewage Stabilization Lagoons. Editorial: Colombian School of Engineering, Colombia, Bogota, 58-65.

[22] Fan, L., Hair, R., Wang, W., Lu, Z. and Yang, Z. (2008) Application of Computational Fluid Dynamic to Model the Hydraulic Performance of Subsurface Flow Wetlands. Journal of Environmental Sciences, 20, 1415-1422.

[23] Blade, E., Cea, L., Corestein, G., Escolano, E., Puertas, J., Vazquez C., Dolz, J. and Coll, A. (2014). Iber: Numerical Simulation Tool for Flow in Rivers. International Journal of Numerical Methods for Calculation and Design in Engineering, 30, 1-10.

[24] Lloyd, B., Leitner, A., Vorkas, C. and Guganesharajah, R. (2003) Under-Performance and Rehabilitation Strategy for Waste Stabilization Ponds in Mexico. Water Science and Technology, 48, 35-34.

[25] Kayombo, S., Mbwette, T.S., Mayo, A.W., Katima, J.H. and Jogersen, S.E. (2002) Diurnal Cycles of Variation of Physical-Chemical Parameters in Waste Stabilization Ponds. Ecological Engineering, 18, 287-291.

\section{Submit or recommend next manuscript to SCIRP and we will provide best} service for you:

Accepting pre-submission inquiries through Email, Facebook, LinkedIn, Twitter, etc. A wide selection of journals (inclusive of 9 subjects, more than 200 journals)

Providing 24-hour high-quality service

User-friendly online submission system

Fair and swift peer-review system

Efficient typesetting and proofreading procedure

Display of the result of downloads and visits, as well as the number of cited articles

Maximum dissemination of your research work

Submit your manuscript at: http://papersubmission.scirp.org/

Or contact jep@scirp.org 